\title{
Genre-Based Approach: Its Contribution to The Quality of Teaching And Learning Process
}

\author{
Siti Fathonah Wijayanti, Joko Nurkamto and Hefy Sulistyawati
}

\author{
English Education Department \\ Teacher Training and Education Faculty \\ Sebelas Maret University of Surakarta
}

Email: sitifathonahwijayanti@gmail.com

\begin{abstract}
The article aims at describing the implementation of Genre-Based Approach (GBA) in the teaching of English and identifying its contribution to the quality of teaching and learning process. A naturalistic inquiry was conducted at the eleventh grade of a Senior High School in Central Java, Indonesia. The findings of the study suggest that GBA contributes positively to the teaching and learning process in that it helps developing learners' productive skills. Nevertheless, insufficient scaffolding during the learning process resulted in learners' skills which are superficial rather than communicative in nature. Such insufficient scaffolding is arguably related to inappropriate activities during the joint construction stage, partial application of the Curriculum Cycle, and the absence of integrated grammar teaching during the teaching and learning process. Contextual factors such as the lack of planning and inadequate teacher training are of major contribution to the phenomenon.
\end{abstract}

Keywords: genre-based approach, scaffolding, English teaching, quality of teaching and learning, naturalistic inquiry

\section{INTRODUCTION}

English language curriculum as a part of Indonesian national curriculum has attempted to make some changes especially in the use of certain language teaching methodology which best equip learners in exploring their potentials. This change is in fact inseparable from the shift of paradigm towards language. The latest paradigm in which language is seen as a means of communication sets communicative competence as the ultimate goal of learning English. It is therefore, learning English should ideally cover all aspects of this competence, namely discourse, sociocultural, linguistic, formulaic, interactional, and strategic competences (Celce-Murcia, 2007).

The government of Indonesia, through the Ministry of National Education, has already set out some regulations concerning this matter. Through the 2004 Curriculum known as KBK (Competencebased Curriculum) which is further developed into the recent KTSP (Schoolbased Curriculum), Genre-Based Approach (GBA) is advocated. This approach is seen as the best methodology for a text-based curriculum which is incorporated in the KTSP (see Nugroho \& Hafrizon, 2009).

Genre-Based Approach (GBA) is an approach aimed at providing learners with access to various genres of written and spoken texts which are deemed crucial or powerful for learners to interact in the society (Dufficy, as cited in Adamson, 2004). Underpinned by Halliday's (1985a) Systemic Functional Linguistics (SFL) theory as well as Vygotsky's and Bruner's (as cited in Nugroho and Hafrizon, 2009) 
notions of ZPD and scaffolding, GBA is widely applied through various procedural steps known as the Curriculum Cycle which involves stages of Building Knowledge of Field, Modelling of Text, Joint-Construction of Text, and Independent Construction of Text. Additional stage, i.e., Linking the Related Texts is also encouraged to be employed (see Agustien, 2006; Richards, 2006, pp. 39-41).

Gaining its popularity in the new millennium, GBA "has influenced the entire state educational system in Australia, and has been adopted in primary, secondary, tertiary, professional and community teaching contexts in programs for native speakers of English as well as ESL and EFL learners" (Derewianka, 2003). Other countries such as Singapore, South Africa, USA, Italy, Hong Kong, Australia, UK, China, Canada, Sweden and Thailand are also employing GBA in developing their syllabuses, materials and curricula (ibid.).

Despite its rising popularity, the implementation of GBA in the ELT context is still facing a number of challenges. Researches (Burns and Knox, 2005; Richards, 2006) notify that the application of GBA in teaching the four skills is still considered difficult for teachers. This approach has yet to be widely known and its related pedagogies have been claimed as being too "recipe-like", prescriptive, and likely to hamper creativity. Besides, this approach is deemed repetitive and boring as the similar cycle is applied to teaching all four skills.

My initial observation on a Senior High School in Indonesia further reveals that some challenges exist during the implementation of GBA. The curriculum cycle employed sometimes resulted in students' boredom, especially when it came to reading activities with students being frequently exposed to similar procedures in learning various genres. Meanwhile, when teachers tried varying the activities into more enjoyable activities, the accuracy aspect seemed to be neglected. Learners were mostly encouraged to speak up but they showed poor grammatical accuracy, as suggested by the results of the test. Another problem found is that most of the students did not fully understand what they have learnt, in contrary to their active participation during the lesson. Such phenomena thus arouse such questions as: How is the notion of GBA set out in the curriculum? How do teachers actually perceive the notion of GBA? What are the challenges during GBA implementation and what are the possible solutions to deal with such challenges? How could grammar be best accommodated through GBA? And so forth.

There have actually been numerous studies on GBA, especially in the ESL and EFL context. However, the studies mostly focus on the L2 writing related themes in the tertiary level education (e.g., Lin, 2006; Widodo, 2006). Meanwhile, studies on the implementation of GBA in Indonesian EFL classroom context, particularly in teaching integrated skills (i.e., listening, speaking, reading, and writing), are still limited in number. To fill such a gap in the literature, this study was particularly focused on investigating the implementation of GenreBased Approach in the teaching of English in EFL Secondary School Context in Indonesia. Further, it sought to identify the contribution of GBA to the quality of teaching and learning process.

\section{RESEARCH METHODS}

Employing qualitative method in the form of naturalistic inquiry (see Lincoln \& Guba, 1985), this study focused on the GBA 
implementation in the eleventh grade of a Senior High School in Central Java, Indonesia. One English teacher and 55 students from three different classes participated in this study.

Classroom observations, in-depth interviews, and documents analysis were deployed to collect the information related to the genre-based teaching and learning activities. Observations on three different classes, i.e., Class XI Social Science 1, XI Natural Science 5, and XI Natural Science 7 were aimed to obtain general representation of genre-based teaching and learning activities in the school. Interviews to one English teacher and nine students were done to generate narratives about the classroom situation when GBA is implemented as well as how teacher and students felt during the implementation. Documents in the form of teaching and learning materials, samples of students' writings, sample of presentation checklist, as well as field notes on observations and interviews were also analyzed to support the data. The data were then analyzed using Miles and Huberman's Interactive Model, which includes data reduction, data display, and conclusion drawing.

The trustworthiness of this study was obtained through technique triangulation, i.e., observations, interviews, and documents analysis; and source triangulation, i.e., teacher and students. In addition, member check was also carried out to ensure that the results of this study met the respondent's perspective. Further, such a thick description was provided to allow readers or other researchers to compare this study to their own contexts.

\section{RESEARCH FINDINGS AND DISCUSSIONS}

The findings of this study suggest that GBA could develop learners' productive skills; nevertheless, insufficient scaffolding during the learning process resulted in learners' skills which are superficial rather than communicative in nature.

Teacher reported that GBA contributes positively towards the teaching and learning process in that it helps developing learners' productive skills. As argued by the teacher, GBA eases learners in producing or creating texts since it provides them with clarity on the purpose, generic structure, as well as language features of particular text. This supports Kay and Dudley-Evans' ideas (1998, p. 310), stating that "genre-based approaches can liberate learners from their own fears of writing by giving them security ('something to fall back on') and offering them models, which were felt to be valuable."

However, the findings yielded on learners showing such superficial skills in their independent construction of text. In delivering their oral presentations, there were some learners who presented exactly the same topic, including the same thesis, the same arguments, and even the same slide design. This is very regrettable as it becomes difficult to value the originality of learners' ideas. Moreover, learners mostly performed memorized speeches and were reading the slides rather than delivering their ideas to convince the audience.

Arguably, learners' performing such superficial skill was triggered by the difficulty of the task or learners' lack of ability to accomplish the task. This further indicates that the scaffolding process has yet to "move learners through their zone of proximal development towards their 
potential level of independent performance" (Nugroho \& Hafrizon, 2009, p. 7).

The notion of scaffolding in genrebased learning is closely related to teacher's role as an interventionist who provides help and guides learners from the first stage of learning until learners are able to independently create their own text. In this way, teacher is seen as the one who should model the social purpose of text type, jointly construct with learners a model text using appropriate grammatical structures, and consult with learners during their independent construction of texts (Christie, 2004; Coe \& Freedman, 1998; Gray, as cited in Nugroho \& Hafrizon, 2009). Actually, teacher had played her role as an interventionist during the learning process by providing models and jointly constructing the text with learners. Nevertheless, the fact that learners were eventually not performing the target competence leads to such question as how effective the scaffolding offered by the teacher.

Taking a closer look to the task given by the teacher, instead of constructing 'spoken' text in the JCT stage, learners were constructing 'written' text by discussing certain topic with their partner. Such activity hence contradicts the different nature of spoken and written text which becomes a consideration in adopting GBA (Departemen Pendidikan Nasional, 2003, p. 12-13; Halliday, 1985a, p. xxiv; Halliday, 1985 b, pp. 30-31, 92-96). As the task was eventually aimed at learners presenting an argumentative speech, the series of scaffolding should actually concerned on providing learners sufficient exposure on the modelled text as well as an 'experience of creating similar text' with their peers, with the help of the teacher. In this case, the class could practice delivering their opinions about certain topic raised by the teacher, for example. Alternatively, teacher might divide learners in pairs and assign them to have a role play on discussing or arguing about a topic from the alternatives provided by the teacher or other topics which might interest them. The point is that learners should be experiencing the process of creating the text (Agustien, 2006) with the help of teacher before they independently create it.

In addition to inappropriate activities in regard to the given task, insufficient scaffolding was also related to the way the Curriculum Cycle was applied. Basically, teacher did not observe the Curriculum Cycle as suggested in the curriculum. In teaching Exposition text, the MOT, JCT and ICT stages were employed while the stage of Building Knowledge of the Field (BKOF) was not observed at all.

As Feeze and Joyce (as cited in Richards, 2006) suggest, learners are need to be made aware of the cultural context as well as the context of situation of the text being studied in the earlier stage of the lesson. One of the key element in this stage is investigating the register which involves building knowledge of the topic of the model text and knowledge of the social activity in which the text is used, understanding the roles and relationships of the people using the text and how these are established and maintained, and understanding the channel of communication being used. Such activities, in fact, were absent on the teaching and learning process lead by teacher DR; thus resulted in learners' lack of awareness of the nature of the text they created.

In the earlier stage of lesson, teacher attempted to play a debate video and asked learners some questions. However, the questions were mainly to elicit learners' understanding of the content of the text, 
such as asking about the main idea and detailed information on the text, and additionally, identifying the generic structure of the text. This activity represents the stage of modelling the text (MOT), to which Feez and Joyce (as cited in Richards, 2006, p. 40) refer as "the stage that many traditional ESL language teaching activities come into their own".

After modelling the text, teacher together with learners were jointly constructing the text (JCT). In the joint construction of the Exposition text, teacher grouped learners in pairs and asked them to create a 'similar' text like the modelled text. The activities in this stage were in line with the principle of GBA in that language learning should be in a form of social activity and include collaboration between the teacher and the learner(s) and between the learner and the other learners in the group (Feez \& Joyce, as cited in Agustien, 2006). However, the text learners jointly constructed (i.e., written text) and the text they later presented (i.e., spoken text) were not 'similar'. Thus, albeit opening opportunities for learners to use language through interaction, the intended goal can hardly be achieved with such inappropriacy.

Another noteworthy point related to insufficient scaffolding is the absence of integrated grammar teaching during the English lesson, which contradicts the notion of GBA. As noted by Hyland (as cited in Herawati, 2009, p. 19), "Genre teaching involves being explicit about how texts are grammatically patterned, but grammar is integrated into the exploration of texts and

contexts rather than taught as a discrete component." GBA is thus seen as an "opportunity for to teaching grammatical structures in context” (Derewianka, 2003), hence teachers can "help learners not only to see how grammar and vocabulary choices create meanings, but to understand how language itself works, acquiring a way to talk about language and its role in texts (Hyland, as cited in Herawati, 2009, p. 19)." In fact, the time constraint and the demand for passing final examination made teacher

focus heavily on the text 'content' and neglecting the grammar, although teacher was actually aware of the importance of grammar. Teacher acknowledged the idea of raising learners' awareness of language features; however, such idea was deemed ineffective and time-

consuming. Moreover, teacher needed to ensure that the text types or genres included in the curriculum were all covered. Thus, teacher 'sacrificed' the integrated teaching, and alternatively, grammar is taught separately at the last semester of twelfth grade for preparing learners to face final examination and further studies. Such discrete teaching, unfortunately, cannot really help learners in achieving communicative competence (Savignon, 2002, p. 7).

Arguably, such discrete teaching of grammar was due to teacher's insufficient knowledge of the pedagogical application of GBA in the classroom (see Burns and Knox, 2005). Burns and Knox further suggest a curricular improvement for teacher education, particularly in providing studentteachers with explicit tools for pedagogy, including demonstrating explicit models of teaching in order to enable them to effectively apply SFL-based pedagogy in the classroom.

The above three factors indicating insufficient scaffolding, i.e., the inappropriate activities in the joint construction stage, the partial application of the Curriculum Cycle, and the absence of integrated grammar teaching through texts, are all attributed to teacher. However, in 
analyzing how such insufficient scaffolding occurred at the first place, other contextual factors, such as the lack of planning in implementing GBA in the school and the inadequate trainings teacher received to implement this approach should also be taken into account.

In regard to the GBA planning in the school, the findings reveal that there was an absence of specific syllabus and lesson plans for the eleventh grade. Actually, the English syllabi for all grades in the school were adapted from the syllabus from BSNP and IGCSE. It is teacher's duty, then, to develop her own syllabus based on the needs of each grade she teaches. As a matter of fact, teacher made neither specific syllabus nor lesson plans for the eleventh grade. It was due to teacher's belief that such documents do not contribute much to the teaching and learning process as in most cases learning activities go unlike what has been planned before (see Farrell, 2002, p. 32; Richards and Lockhart, 1996, p.82).

Taking into account the way teacher prepared the lesson, it is likely that teacher did what is called mental plan ("Lesson Planning and Classroom Management," 2002). Even though teacher did not write the lesson plan in detail, she designed her lesson from the indicators and content standards in the IGCSE syllabus and a syllabus from BIMTEK, a national-scaled English teacher training held by the Ministry of Education. However, whether this attempt succeeded in bringing "an engaging and effective lesson" (ibid.) is somehow questionable. In fact, the absence of lesson plan violates the process standard set in the curriculum in which teacher is actually obliged to develop a complete and systematic lesson plan in order to realize such an effective learning (see Direktorat Pembinaan Sekolah Menengah Atas, Direktorat Jenderal Manajemen
Pendidikan Dasar dan Menengah, Departemen Pendidikan Nasional, 2008).

Broadly speaking, teacher's negligence of the importance of syllabus and lesson plan might not merely reflect teacher's belief on teaching and learning as earlier noted, but also stemmed from the contextual factor which is the absence of MGMP's role in providing the appropriate guidance in developing the syllabus. The absence on guidance led to the absence on classification of language features on each text type or genre to teach. This led to such overlapping materials where certain tenses or structures were taught frequently while others were left untouched at all. Moreover, the curriculum does not include specific themes for the materials in each grade, leading to teacher's confusion in designing the lesson. This indefinite formulation of materials brings more burdens to teacher since such formulation ought to be the task of syllabus designers and textbook writers (see Derewianka, 2003).

Problems such as the absence of detailed classification on linguistic features and the 'too-wide' coverage of themes are actually 'old' problems which have been addressed since the earlier period of GBA implementation in Indonesia (see Pusat Kurikulum, Badan Penelitian dan Pengembangan, Departemen Pendidikan Nasional, 2007, p. 25). However, there seems to be no tangible solution towards this matter. The government has actually attempted to provide a number of in-service trainings for teachers which are supposed to enlighten teachers with this novel approach. Nevertheless, such trainings are not regarded as really helpful as there are still many teachers who are not concerned with the notion of GBA even after it is implemented. Teachers, in fact, tend to see curriculum changes only as common 
administrative changes which bring no significant effects towards teaching and learning process.

The findings also reveal that almost all the teachers in the school tend to work independently. Collaborative teamwork is not working, worsened by many teachers' resistance towards changes. Regarding the in-service trainings, teachers are not intensively trained as such trainings usually held only when there is a 'block grant' and the school usually delegate different teachers hence such comprehensive understanding on the 'new concepts' provided in the trainings can be hardly expected. Those contextual factors supported Mohamed's findings (2006, pp. 236-237) on the reasons why in-service trainings are not rated so highly by teacher. A study by Yuwono in 2005 (as cited in Yuwono \& Harbon, 2010) further echoes such phenomenon, stating that the condition where teachers are forced to work in isolation with inadequate support from policymakers and/or other related stakeholders is believed to cause scepticism, confusion, ignorance, reluctance, unwillingness, or even resistance instead of growing them as professionals.

\section{CONCLUSIONS AND SUGGESTIONS}

The findings of this study lead to a main conclusion that Genre-Based Approach contributes positively to the teaching and learning process in that it helps developing learners' productive skills; nevertheless, insufficient scaffolding during the learning process resulted in learners' skills which are superficial rather than communicative in nature. This supports the previous theories stating that GBA can improve learners' productive skills (Herawati, 2009; Kay \& Dudley-Evans, 1998) yet in some ways modifies them by placing the importance of scaffolding in achieving learners' overall communicative competence and further clarifies how insufficient scaffolding could lead to such superficial rather than communicative skills.

The study further examined factors influencing such insufficient scaffolding which are still less explored in the GBArelated studies particularly in Indonesian

ELT context. Thus, it is expected that through this study English teachers in Indonesia can reflect on and improve their teaching practices so as to help learners achieving the communicative competence.

Finally, there is a call for supports from any related stakeholders, including the school, the teacher training program, and the curriculum designer and/or policy maker, so that the implementation of GBA could be at its best in the long run. The school should provide opportunities for teachers to always enhance their professional competence, e.g., providing workshops/seminars inviting experts on the field. Collaborative working atmosphere among teachers also needs to be established thus any changes for the betterment of learning could eventually be achieved. Meanwhile, teacher training program could serve to provide initial training on GBA, by providing studentteachers with both theoretical knowledge of SFL as the underpinning theory of GBA and explicit tools for pedagogy, including demonstrating explicit models of teaching using SFL-based pedagogy or GBA. The curriculum designer and/or policymaker also need to provide a thorough syllabus design which leaves no room for misinterpretation or confusion among teachers, and further conduct sustainable and effective in-service trainings on GBA.

As this study only concerns on a specific school with all its peculiarities, the findings of this study can therefore be 
applied to limited context. Further researches involving wider participants on the implementation of GBA in the Indonesian EFL classroom context hence need to be conducted. Another important issue, i.e., how grammar could be best accommodated in the genre-based teaching and learning process also leaves a room for further investigation.

\section{BIBLIOGRAPHY}

Adamson, B. (2004). Fashions in Language Teaching Methodology. In A. Davies \& C. Elder (Eds.). The Handbook of Applied Linguistics (pp. 604-622). MA: Blackwell Publishing.

Agustien, H.I.R. (2006). Genre-Based Approach and the 2004 English Curriculum. A Plenary Paper Presented at UPI National Seminar, UPI Bandung on 24 ${ }^{\text {th }}$ February.

Burns, A. \& Knox, J. (2005). Realisation(s): Systemic Functional Linguistics and Language Classroom. In N. Bartels (Ed.). Applied Linguistics and Language Teacher Education (pp. 235-260). Boston: Springer.

Celce-Murcia, M. (2007). Rethinking the Role of Communicative Competence in Language Teaching. In E. Alcón Soler \& M.P. Safont Jordà (Eds.). Intercultural Language Use and Language Learning (pp. 41-57). The Netherlands: Springer.

Christie, F. (2004). Authority and Its Role in the Pedagogic Relationship of Schooling. In L. Young \& C. Harrison (Eds.). Systemic Functional Linguistics and Critical Discourse Analysis (pp. 173-201). London: Continuum.
Coe, R.M. \& Freedman, A. (1998). Genre Theory: Australian and North American Approaches. In M.L. Kennedy (Ed.). Theorizing Composition, A Critical Sourcebook of Theory and Scholarship in Contemporary Composition Studies (pp. 136-147).

Departemen Pendidikan Nasional. (2003). Kurikulum 2004, Standar Kompetensi Mata Pelajaran Bahasa Inggris Sekolah Menengah Atas dan Madrasah Aliyah. Jakarta: Departemen Pendidikan Nasional.

Derewianka, B. (2003). Trends and Issues in Genre-Based Approaches. RELC Journal, 34, 133-154. Retrieved from http://rel.sagepub.com.

Direktorat Pembinaan Sekolah Menengah Atas, Direktorat Jenderal Manajemen Pendidikan Dasar dan Menengah, Departemen Pendidikan Nasional. (2008). Pengembangan Rencana Pelaksanaan Pembelajaran (RPP). Jakarta: Departemen Pendidikan Nasional.

Farrell, T.C. (2002). Lesson Planning. In J.C. Richards \& W.A. Renandya (Eds.). Methodology in Language Teaching, An Anthology of Current Practice (pp. 30-39). Cambridge: Cambridge University Press.

Halliday, M.A.K. (1985a). An Introduction to Functional Grammar. London: Edward Arnold.

Halliday, M.A.K. (1985b). Spoken and Written Language. Oxford: Oxford University Press.

Herawati, H. (2009). The Implementation of Genre-Based Approach in the Teaching of English at SMA N 1 
Karanganyar and Its Effects in Promoting Students' Critical Thinking (A Naturalistic Study at SMA Negeri 1 Karanganyar in 2009). (Unpublished Master Degree Thesis). English Education Department. Graduate School. Sebelas Maret University, Surakarta.

Kay, H. \& Dudley-Evans, T. (1998). Genre: What teachers think. ELT Journal, 52 (4), 308-314. Retrieved from http://eltj.oxfordjournals.org.

Lesson Planning and Classroom Management. (2002). In J.C. Richards \& W.A. Renandya (Eds.) Methodology in Language Teaching, An Anthology of Current Practice (p. 27-29). Cambridge: Cambridge University Press.

Lin, B. (2006). Genre-based Teaching and Vigotskyan Principles in EFL: The Case of a University Writing Discourse. Asian EFL Journal, 8 (3). Retrieved from http://www.asian-efljournal.com.

Lincoln, Y.S. \& Guba, E.G. (1985). Naturalistic Inquiry. Beverly Hills: Sage Publications, Inc.

Mohamed, N. (2006). An Exploratory Study of the Interplay between Teacher's Beliefs, Instructional Practices \& Professional Development. (Ph.D. Thesis). The University of Auckland, Auckland, New Zealand.

Nugroho, T. \& Hafrizon. (2009). Introduction to Genre-Based Approach. Center for Development and Empowerment of Language Teachers and Education Personnel, Directorate General of Quality
Improvement of Teachers and Education Personnel, Ministry of National Education.

Pusat Kurikulum, Badan Penelitian dan Pengembangan, Departemen Pendidikan Nasional. (2007). Naskah Akademik Kajian Kebijakan Kurikulum Mata Pelajaran Bahasa. Jakarta: Departemen Pendidikan Nasional.

Richards, J.C. (2006). Communicative Language Teaching Today. Cambridge: Cambridge University Press.

Richards, J.C. \& Lockhart, C. (1996). Reflective Teaching in Second Language Classroom. Cambridge: Cambridge University Press.

Savignon, S.J. (2002). Communicative Language Teaching: Linguistic Theory and Classroom Practice (pp. 1-27). In S.J. Savignon (Ed.). Communicative Language Teaching, Contexts and Concerns in Teacher Education. New Haven: Yale University Press.

Widodo, H. (2006). Designing a genrebased lesson plan for an academic writing course. English Teaching: Practice and Critique, 5 (3), 173199. Retrieved from http://education.waikato.ac.nz/resear ch/files/etpc/2006v5n3nar2.pdf.

Yuwono, G.I. \& Harbon, L. (2010). English Teacher Professionalism and Professional Development: Some Common Issues in Indonesia. Asian EFL Journal, 12 (3), 145-163.

Retrieved from http://www.asian-efljournal.com. 